doi: 10.18484/2305-0047.2019.5.530

\author{
P.G. KRAVCHUN ${ }^{1}$, M.I. KOZHYN ${ }^{1}$, F.S. LEONTIEVA ${ }^{2}$, \\ P.M. VORONTSOV ${ }^{2}$, N.A. ASHUKINA ${ }^{2}$, O.P. MARUSHCHAK ${ }^{2}$, \\ V.YU. DIELIEVSKA ${ }^{1}$
}

\title{
REVEALING WEAK A AND B ANTIGENS IN PATIENTS WITH KNEE AND HIP JOINT ARTHROPLASTY
}

\author{
Kharkiv National Medical University ${ }^{1}$, \\ Institute of Spine and Joint Pathology named after M. I. Sytenko ${ }^{2}$, Kharkiv, \\ Ukraine
}

Цель. Провести анализ методов выявления слабых А и В антигенов на эритроцитах в системе АВ0.

Материал и методы. Проведено обследование пациентов с эндопротезированием коленного и тазобедренного суставов с целью определения группоспецифической принадлежности с выявлением слабых А и В антигенов на эритроцитах. Использованы методы абсорбции, реакция агглютинации, агглютинация в присутствии комплемента и антиглобулиновый тест.

Результаты. Антиглобулиновый тест с использованием как поликлональной сыворотки, так и сыворотки, содержащей только IgG антитела, позволил выявить слабые А и В подгруппы на эритроцитах при $37^{\circ} \mathrm{C}$. В реакции абсорбции с анти-А, анти-В поликлональными сыворотками у некоторых пациентов на эритроцитах выявлены А и В антигены, также проявившиеся в реакции агглютинации при $37^{\circ} \mathrm{C}$, но не обнаруженные при инкубации при комнатной температуре. Агглютинационный тест с использованием комплемента и сыворотки с IgG антителами также способствовал проявлению слабых антигенов. Присутствие $\mathrm{IgG}$ антител было определено после обработки сыворотки унитиолом в антиглобулиновом тесте. Наличие в сыворотке только IgG антител, соответствующих антигенам, при участии комплемента приводило к более выраженным изменениям эритроцитов по сравнению с присутствием обоих классов антител - IgM и $\operatorname{IgG}$.

Появление гемолиза ассоциировалось с увеличением размеров эритроцитов и гипохромией. Присутствие слабых подгрупп в большинстве случаев было ассоциировано с гемолизирующими, а не агглютинирующими свойствами сыворотки пациента, а также наличием комплементсвязывающих IgG антител.

Заключение. Применение абсорбции, агглютинация при $37^{\circ} \mathrm{C}$, антиглобулиновый тест при $37^{\circ} \mathrm{C}$ с сывороткой, как подвергшейся, так и не подвергшейся обработке унитиолом, а также реакция агглютинации с использованием комплемента способствовали определению слабых антигенов в системе АВ0.

Ключевые слова: антиген, кровь, антиглобулин, комплемент, эритроциты

Objective. To analyze the methods of revealing weak A and B antigens on the erythrocytes in AB0 system.

Methods. Patients after knee and joint arthroplasty were examined on group-specific characteristics with revealing weak A and B antigens on the erythrocytes. Methods of absorption, agglutination, agglutination with complement and antiglobulin test were used.

Results. Antiglobulin test with the use of polyclonal serum as well as serum containing the only IgG allowed revealing weak A and B subgroups on erythrocytes at $37^{\circ} \mathrm{C}$. In some patients A and B antigens on erythrocytes were found while absorption with anti-A, anti-B polyclonal sera and also revealed in agglutination at $37^{\circ} \mathrm{C}$, but were not revealed while incubation at the room temperature. Agglutination test with the use of complement and IgG was also helpful in determining the weak antigens. Presence of IgG antibodies was revealed by the treatment of the serum with unithiol in antiglobulin test. Presence of complement and only IgG antibodies corresponding to the antigens led to the more expressed changes of erythrocytes as compared to the presence of both types of antibodies $-\operatorname{IgM}$ and $\operatorname{IgG}$.

Appearance of hemolysis was associated with the increased sizes of erythrocytes and hypochromia. Presence of weak subgroups was mostly associated with hemolytic rather than agglutinating abilities of the patient's serum, as well as with the presence of complement binding IgG antibodies.

Conclusions. Absorption, agglutination at $37^{\circ} \mathrm{C}$, antiglobulin test at $37^{\circ} \mathrm{C}$ with serum both treated and nontreated with unithiol and agglutination with use of the complement helped to define weak antigens in AB0 system.

Keywords: antigen, blood, antiglobulin, complement, erythrocytes

Novosti Khirurgii. 2019 Sep-Oct; Vol 27 (5): 530-540

The articles published under CC BY NC-ND license

Revealing Weak A and b Antigens in Patients with Knee and Hip Joint Arthroplasty

P.G. Kravchun, M.I. Kozhyn, F.S. Leontieva, P.M. Vorontsov,

N.A. Ashukina, O.P. Marushchak, V.Yu. Dielievska

\section{Научная новизна статьи}

Впервые проанализированы методы выявления слабых А и В антигенов на эритроцитах в АВ0 системе. Установлено, что агглютинация эритроцитов с поликлональной сывороткой при $37^{\circ} \mathrm{C}$, антиглобулиновый тест при $37^{\circ} \mathrm{C}$ и реакция агглютинации с комплементом способствуют выявлению слабых А и В антигенов. 
Установлено усиление комплементзависимого гемолиза эритроцитов при отсутствии соответствующих группоспецифических $\operatorname{IgM}$ и наличии только $\operatorname{IgG}$ антител. Обработка унитиолом поликлональной сыворотки при $37^{\circ} \mathrm{C}$ способствует выявлению IgG анти-А и анти-В антител в антиглобулиновом тесте.

\section{What this paper adds}

For the first time, methods for the detection of weak A and B antigens on erythrocytes in AB0 system have been analyzed. Agglutination of erythrocytes by polyclonal serum at $37^{\circ} \mathrm{C}$, antiglobulin test at $37^{\circ} \mathrm{C}$ and agglutination with complement has been established to promote the detection of weak A and B antigens. Enhancement of complement dependent hemolysis of erythrocytes in the absence of group-specific $\operatorname{IgM}$ and presence of only $\operatorname{IgG}$ antibodies has been found out. The treatment of polyclonal serum with unithiol at $37^{\circ} \mathrm{C}$ helps to identify $\operatorname{IgG}$ anti-A and anti-B antibodies in the antiglobulin test.

\section{Introduction}

AB0 blood groups are most important for blood transfusion. Weak subgroups are phenotypically rare and often not detected when typing blood groups, since these types of antigens are very poorly represented on the erythrocyte membrane and cannot be detected by conventional methods [1]. A number of authors discuss the advantages and disadvantages of individual methods in identifying weak antigens [2]. However, there is no consensus on the most effective way to detect weak AB0 antigens. A number of methods are proposed that are used in the diagnosis of weak $\mathrm{AB} 0$ blood subgroups. So, only a set of methods for determining weak B antigens and antibodies allows identifying type $B$ antigen on erythrocytes [3].

In routine determination of group affiliation according to $\mathrm{AB} 0$, anti- $\mathrm{A}$, anti- $\mathrm{B}$ and anti- $\mathrm{AB}$ antibodies are used to test erythrocytes. Most antibodies of blood groups $\mathrm{AB} 0$ are IgM and are better detected at $4^{\circ} \mathrm{C}$. The determination of blood groups in laboratories is carried out by direct rather than the reverse method, and the sequence of actions for determining a particular weak subgroup has not been defined. Weak antigens may not be detected, and typing results may become incorrect.

With a large volume of surgical intervention, blood transfusion is one of the necessary components in the management of patients with knee and hip arthroplasty. The accuracy in determining the blood group and weak antigens in these patients is extremely important, since improper typing of the blood group can lead to irreversible consequences. In orthopedics and traumatology clinics, various methods of typing blood groups are not widely used due to the lower frequency of blood transfusions, in contrast to hematological clinics. However, patients of this profile also need the correct typing of weak subgroups and a description of the most effective methods for their determination will avoid blood transfusion complications. Thus, there is a need to analyze methods for identifying weak subgroups of the AB0 system to improve the quality of diagnosis in typing blood groups.

Objective. To analyze the methods of revealing weak $A$ and $B$ antigens on the erythrocytes in $\mathrm{AB} 0$ system.

\section{Methods}

A detailed examination of patients with knee and/or hip arthroplasty requiring blood transfusion during arthroplasty was performed. Clinical observations of 10 patients are presented and blood samples with the determination of the blood group of the $\mathrm{AB} 0$ system using various methods are investigated. A study was also conducted on the susceptibility of erythrocytes to hemolysis and agglutination under the action of sera in 23 patients with blood group A, 10 patients with group B and 10 patients with group 0 with determination of hemolizing properties of the serum. Serological reactions were performed using standard protocols [4]. The neutralization of IgM anti-A and anti-B antibodies was carried out by a drug containing thiol groups - dimercaprol (unithiol) with a modification of the method [2]. So, one volume of each serum sample was mixed with an equal volume of unithiol and exposed at $37^{\circ} \mathrm{C}$ for 1 hour. Sera were tested for the presence of IgG anti-A or anti-B antibodies by their ability to agglutinate in test tubes. Two volumes of serum after treatment with unithiol were mixed with one volume of $3 \%$ suspension of erythrocytes A or B and incubated at $37^{\circ} \mathrm{C}$ to stimulate agglutination for 1 hour. Samples were then examined macroscopically and microscopically for agglutination. Serum with the presence of agglutinating IgG anti-A or anti-B antibodies was fixed.

\section{Results}

In the routine determination of blood type in 10 patients, blood groups $\mathrm{O}(\mathrm{n}=5)$ and $\mathrm{A}(\mathrm{n}=5)$ were determined. In a more detailed study of erythrocytes samples and serums in 8 patients, the presence of weak antigens $A(n=4)$ and $B(n=4)$ on the erythrocyte membrane was determined. We present clinical observations describing the methods used in typing weak subgroups.

Case 1. The patient was admitted for arthroplasty for coxarthrosis. Before surgery, his blood type was identified as $\mathrm{A}(\mathrm{Rh}-)$ (negative). His autocontrol test was negative, and the erythrocytes were agglutinated with anti-A $\operatorname{IgG}$ in the complement reaction and in 
the antiglobulin test. Upon cross-reaction with the donor $\mathrm{A}(\mathrm{Rh}+)$ (positive), his sample was recognized as incompatible. Additional tests were performed on the typing of the group according to $\mathrm{AB} 0$ (tables 1-3).

His erythrocytes were also agglutinated with polyclonal anti-B serum at $37^{\circ} \mathrm{C}$ in the antiglobulin test and anti-B IgG in the reaction with complement and in the antiglobulin test. The erythrocytes of the patient inhibited the reaction of anti-B with erythrocytes. Substance B was present on his erythrocytes, inhibiting the response of anti-B and $\mathrm{B}$ cells. His serum weakly reacted with B erythrocytes; however, agglutination did not appear in the antiglobulin test and in the presence of complement after treating the serum with unithiol. Thus, weak anti-B IgM and not IgG were present in the sample, since at $37^{\circ} \mathrm{C}$ after treatment with unithiol, serum did not agglutinate $\mathrm{B}$ erythrocytes, and only additional use of rheopolyglucinum led to agglutination. Tables 1 to 3 show the $\mathrm{AB}$ group for the direct typing method and the A group for the reverse one.

Adil Salman in 1976 proposed to isolate weak B antigens as B3, Bx, Bel. According to this classification, Bel erythrocytes do not agglutinate anti-B, only absorb anti-B serum. B3 erythrocytes are weakly agglutinated with anti-B serum. Bx erythrocytes are weakly agglutinated, and weak anti-B antibodies are detected in the blood serum of these individuals, and the ability of the serum to inhibit erythrocytes is present. Therefore, the studied sample belonged to the agglutination group anti-B and $B$ of $A B x$ with the presence of weak anti-B antibodies. It was recommended to transfuse the washed erythrocytes 0 with plasma AB.

Case 2. The patient was admitted with anemia and instability of the endoprosthesis for arthroplasty. Before surgery, his blood was identified as A $(\mathrm{Rh}+)$ (positive). His red blood cells agglutinated anti-A and anti-A, B and did not absorb anti-B.

In a cross-reaction, his serum agglutinated $\mathrm{A}$ erythrocytes at a temperature of $37^{\circ} \mathrm{C}$ in the presence and absence of complement without hemolysis, but hemolysis manifested itself after application of the LISS solution, and weak erythrocyte hemolysis was also detected after treating his serum with unithiol in the Coombs test. Thus, weak agglutinating and hemolysing anti-A were present in the sample.

His erythrocytes hemolysed anti-B IgG in the antiglobulin test with weak agglutination and showed more pronounced agglutination and slight hemolysis with anti-B IgG in the presence of LISS. In the presence of polyclonal anti-B and complement, his erythrocytes were weakly agglutinated, and in the presence of polyglucin the number of erythrocytes decreased.

Patient's erythrocytes hemolysed in the presence of anti-A and complement, but hemolysis weakened in the presence of LISS and polyglucin.
Patient's serum agglutinated B erythrocytes in a titer of $1: 8$ with hemolysis in the presence of complement, but without hemolysis after treatment with unithiol. Thus, hemolytically active anti-B IgM were present in the sample. His non-hemolytic IgG anti-B antibodies were detected in the indirect Coombs test.

After unithiol treatment, the patient's serum agglutinated his own red blood cells in the indirect antiglobulin test with slight hemolysis. His direct antiglobulin test (DAT) was positive. Performing the test at $37^{\circ} \mathrm{C}$ and $4^{\circ} \mathrm{C}$ showed hemolysis of his erythrocytes at $37^{\circ} \mathrm{C}$; therefore, thermal autoantibodies were present in the sample.

Autosorption:

1. Plasma and erythrocytes at $37^{\circ} \mathrm{C} 15^{\prime}$, washing of red blood cells, the addition of antiglobulin serum (AGS): + aggl., hemolysis, red supernatant.

2. Plasma and eryrhrocytes at $4^{\circ} \mathrm{C} 15^{\prime}$, washing of red blood cells, the addition of AGS: - aggl., no hemolysis, clear supernatant.

His autocontrol test was negative, but became positive with the addition of polyglucin, and there was a slight hemolysis of his erythrocytes and serum with the addition of complement. The serum of this sample did not agglutinate 0 erythrocytes.

Thus, the patient group was defined as A with IgM anti-B antibodies, weak IgG anti-B antibodies, weak thermal agglutinating complement-binding and hemolytic anti-A IgG and thermal autoantibodies (active at $37^{\circ} \mathrm{C}$ ).

Case 3. The patient was assigned $\mathrm{O}$ blood group, however, her erythrocytes reacted with polyclonal anti-B serum at $37^{\circ} \mathrm{C}$ and anti-B IgG. Her erythrocytes were not agglutinated with polyclonal anti-B serum in the presence of complement and anti-B serum after treatment with unithiol in an antiglobulin test. In addition, her red blood cells reacted with polyclonal anti-A in an antiglobulin test, however, anti-A did not agglutinate in the presence of complement.

The patient's own serum in the presence of complement led to weak agglutination without hemolysis. Serum also agglutinated A erythrocytes. The serum contained anti-A IgG antibodies, because after treatment with unithiol it caused hemolysis of A erythrocytes in the Coombs test, as well as in the presence of complement. Serum also agglutinated B erythrocytes in a titer of $1: 9$, and hemolysis was not manifested when complement was introduced.

Possibly, the presence of mixed agglutination of her erythrocytes under the influence of anti-B polyclonal serum containing traces of A antigen may be due to the fixed anti-A antibodies on the patient's erythrocytes. The red blood cells of this sample absorbed anti-B and anti-A antibodies upon absorption. This case was defined as the presence of weak $A$ and $\mathrm{Bx}$ antigens, weak anti-A and anti-B antibodies. 


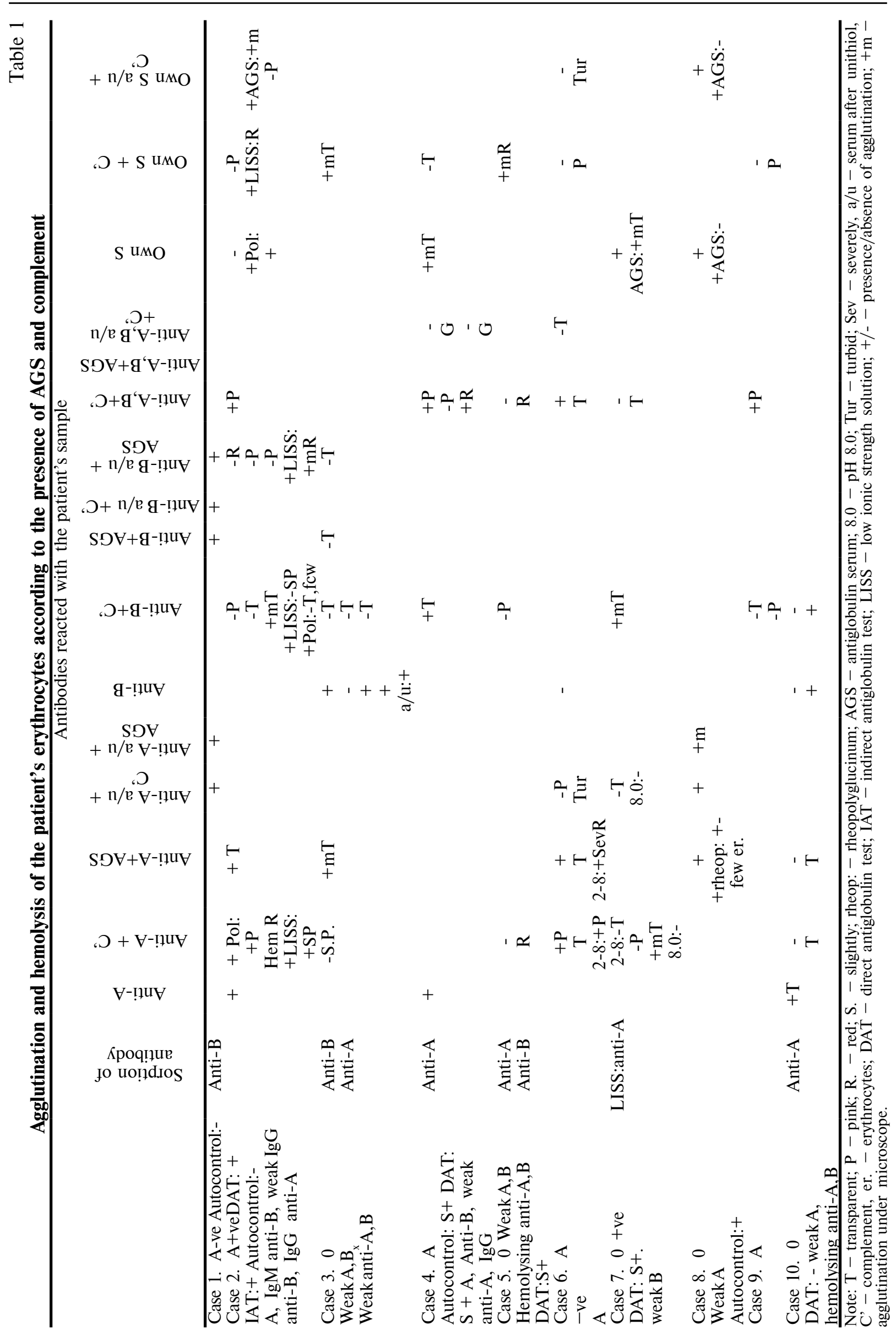


Agglutination and hemolysis of erythrocytes of patients under

Table 2 the action of serum of group $A B$ and autoserum

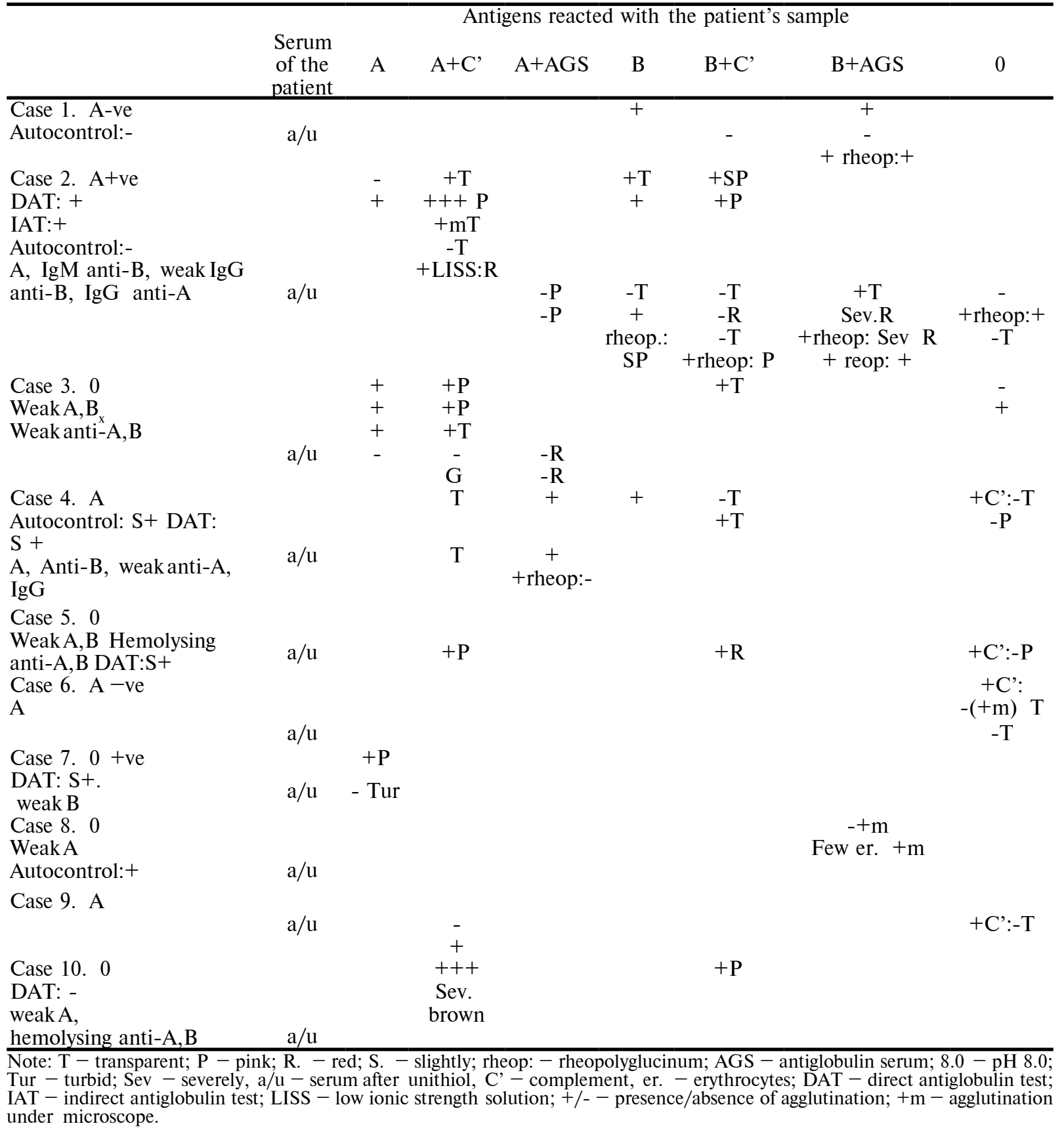

Case 4. The patient was determined blood type A (II). His red blood cells were agglutinated with anti-A and anti-A, B sera with hemolysis in the presence of complement. His erythrocytes were also agglutinated with anti-B serum in the presence of complement without hemolysis. At the same time, his erythrocytes absorbed anti-A and did not weaken the activity of anti-B.

The serum of this patient agglutinated A erythrocytes in the antiglobulin test, but did not lead to hemolysis in the presence of complement. After treatment with unithiol, his serum also agglutinated
A erythrocytes in the antiglobulin test, however, agglutination did not appear when rheopolyglucinum was introduced into the reaction. So, the presence of anti-A IgG was determined.

In the presence of complement, his serum agglutinated B erythrocytes without hemolysis. His autocontrol test and direct antiglobulin test were slightly positive. Thus, the patient was identified as a carrier of antigen A with anti-B and weak anti-A antibodies.

Case 5. The patient was defined as 0 blood group. Her erythrocytes were hemolysed in the 
presence of anti-A and anti-A, B serum and complement. The studied erythrocytes underwent a slight hemolysis in the presence of complement; however, agglutination was not observed.

The patient absorbed anti-B and anti-A antibodies. Her erythrocytes in the presence of her own serum and complement weakly agglutinated with manifestations of hemolysis. The direct antiglobulin test was slightly positive. The patient's serum agglutinated A and B erythrocytes with hemolysis in the presence of complement. So, hemolytically active antibodies were present in the serum of this sample.

Case 6. The patient was assigned the group A (Rh-) (negative).

His erythrocytes were agglutinated with polyclonal anti-A serum and anti-A 2-8 monoclonal antibody (MAB) in the presence of complement with hemolysis. The sample also reacted with antiA, B serum and complement without hemolysis. The red blood cells of the patient were slightly hemolysed under the influence of anti-A IgG and complement.

Table 3

Agglutination and hemolysis of erythrocytes of the patient's serum

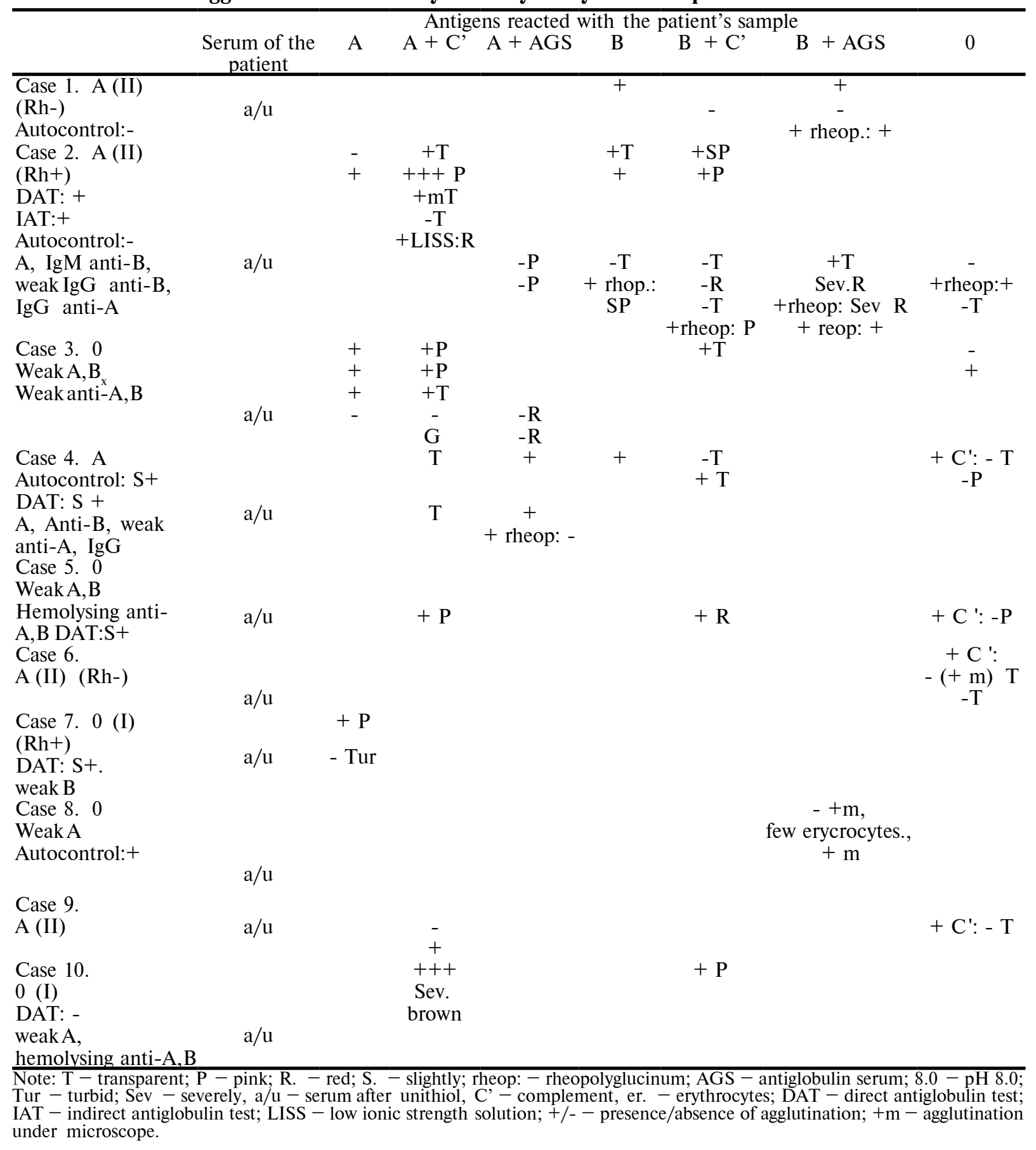


The patient's erythrocytes were agglutinated in the antiglobulin test with polyclonal anti-A serum and anti-A MAB 2-8 (IgG3) in the antiglobulin test with significant hemolysis. In the presence of complement and his own serum treated with unithiol, his erythrocytes were slightly hemolysed. Patient's serum did not agglutinate 0 erythrocytes.

Thus, the case was defined as a carrier of antigen A without the presence of weak antigens.

Case 7. A patient with gonarthrosis and periprosthetic infection, developed 2 years after surgery, was determined blood group $0(\mathrm{Rh}+)$ (positive). Her erythrocytes did not absorb anti-A under normal conditions, only slightly in the presence of physiological saline with low ionic strength (LISS). From the case history one learnt a positive bacteriological growth of Streptococcus hemolyticus (sensitive to fluoroquinolones) in the synovial fluid. Her red blood cells were weakly agglutinated with polyclonal anti-B serum, as well as one of the anti-A serums in the presence of complement.

The patient's serum agglutinated A erythrocytes, however, agglutinating activity was absent after treatment with unithiol. Direct antiglobulin test was weakly positive.

The patient was determined blood type 0 with a weak antigen $\mathrm{B}$. type 0 .

Case 8. The patient was determined blood

She showed the presence of a weak A antigen, manifested in the antiglobulin test with polyclonal anti-A serum at $37^{\circ} \mathrm{C}$, as well as with anti-A IgG in the presence of complement. Her red blood cells were agglutinated with anti-A IgG in the presence of complement, as well as her own serum in the presence of complement. Serum of the sample after treatment with unithiol agglutinated B erythrocytes in the antiglobulin test. So, the presence of a weak A antigen, anti-B and autoantibodies was determined.

Case 9. The patient was determined blood type A.

The patient did not show weak antigens, since anti-B serum in the presence of complement did not contribute to the manifestation of agglutination of the studied erythrocytes.

Case 10. Blood group 0 was determined for the patient. Her erythrocytes absorbed anti-A and agglutinated with polyclonal anti-A at $37^{\circ} \mathrm{C}$, but did not agglutinate in the presence of complement and in the antiglobulin test. Her serum strongly agglutinated A erythrocytes with hemolysis in the presence of complement. Direct antiglobulin test was negative. The patient was determined to have a weak A antigen and hemolytic anti-A and anti-B antibodies.

To analyze the nature of the antigen-antibody binding observed in these methods and to study the state of erythrocytes under the influence of polyclonal antibodies, complement and IgG, these methods were used to detect antigens with the corresponding antibodies, i.e. erythrocytes $\mathrm{A}$ and anti-A and erythrocytes $\mathrm{B}$ and anti-B.

So, incubation of polyclonal anti-A serum and A erythrocytes with complement led to hemolysis and agglutination at $37^{\circ} \mathrm{C}$ (table 4). The use of anti-B and B erythrocytes with complement also led to agglutination, and in some cases, the absence of hemolysis. Anti-A, B serum in the presence of A erythrocytes and complement in most cases also led to hemolysis and agglutination, however, in the reaction with $B$ erythrocytes, hemolysis in the presence of agglutination was less common.

After treatment with unithiol, serum anti-A did not agglutinate A erythrocytes, however, the use of complement in some cases stimulated agglutination. At the same time, agglutination was not observed when anti-B was in contact after treatment with unithiol with B erythrocytes and complement.

Anti-A, B after treatment with unithiol led

Agglutination of erythrocytes in the presence of the complement and antibodies

Table 4

\begin{tabular}{|c|c|c|c|c|c|c|}
\hline & Anti-A + C' & Anti-B + C' & Anti-A,B + C' & Anti-A a/u + C & Anti-B a/u + C' & $\begin{array}{l}\text { Anti-A, B a/u } \\
+C^{\prime}\end{array}$ \\
\hline $\mathrm{A}$ & $\begin{array}{c}+(n=4) \text { severe } \\
\text { hemolysis }(n=1) \\
\text { red }(n=3) \\
\text { turbid }(n=1)\end{array}$ & $\begin{array}{c}-(n=8) \\
+ \text { weak }(n=3) \\
\text { pink }(n=5) \\
\text { transp }(n=5)\end{array}$ & $\begin{array}{c}+(n=4) \\
\operatorname{red}(n=1)+ \\
(n=3) \\
\operatorname{pink}(n=2) \\
\text { transp }(n=1)\end{array}$ & $\begin{array}{c}+(n=1) \\
-(n=1) \\
\text { turbid }(n=1)\end{array}$ & $\begin{array}{l}+(n=2) \\
-(n=1)\end{array}$ & $\begin{array}{c}-(n=2) \text { grey } \\
(n=2)\end{array}$ \\
\hline B & $\begin{array}{c}\text {-red } \\
(n=1)\end{array}$ & $\begin{array}{c}+(n=5) \\
\operatorname{pink}(n=3) \\
\operatorname{transp}(n=2)\end{array}$ & $\begin{array}{c}+(n=5) \\
\operatorname{pink}(n=2) \\
\operatorname{transp}(n=3)\end{array}$ & $\begin{array}{c}+(n=2) \\
\text { red }(n=2) \\
-(n=1) \\
\text { turbid }(n=1)\end{array}$ & $\begin{array}{l}-(n=3) \\
\text { transp }(n=1)\end{array}$ & $\begin{array}{c}-(n=2) \text { transp } \\
(n=1) \text { turbid } \\
(n=1)\end{array}$ \\
\hline 0 & $\begin{array}{c}-(n=4) \\
+ \text { weak }(n=1) \\
\operatorname{pink}(n=1) \\
\text { transp }(n=4)\end{array}$ & $\begin{array}{c}-(n=2) \\
\operatorname{pink}(n=1) \\
\operatorname{transp}(n=2)\end{array}$ & $-\operatorname{transp}(n=1)$ & $\begin{array}{c}-(n=2) \\
+(n=1) \\
\text { transp }(n=2)\end{array}$ & $-(n=1)$ & $-\operatorname{transp} \quad(n=1)$ \\
\hline
\end{tabular}


to hemolysis of A erythrocytes in the presence of complement, while hemolysis with B erythrocytes was less common.

A erythrocytes were more prone to hemolysis than B erythrocytes in the presence of complement and corresponding serum (Fig. 1, 2).

In the reaction of group-specific antibodies and complement, the erythrocyte size were slightly smaller in comparison with the reaction without complement. However, in the presence of hemolysis, erythrocytes became larger in size and hypochromia was observed.

Anti-A serum after treatment with unithiol in the presence of complement led to a more pronounced destruction of red blood cells and their smaller number compared to seras with a complete set of IgM and IgG (Figs. 3, 4). Anti-A, $B$ serum after unithiol treatment and interaction with complement also led to a decrease in the number of red blood cells, their hypochromia, and hemolysis compared to sera containing both $\operatorname{IgM}$ and $\operatorname{IgG}$ (Fig. 5, 6). With 0 erythrocytes, anti-A, anti-B and anti-A, B in the presence of comple-

Fig. 1. Anti-A serum and A red blood cells in the presence of complement.

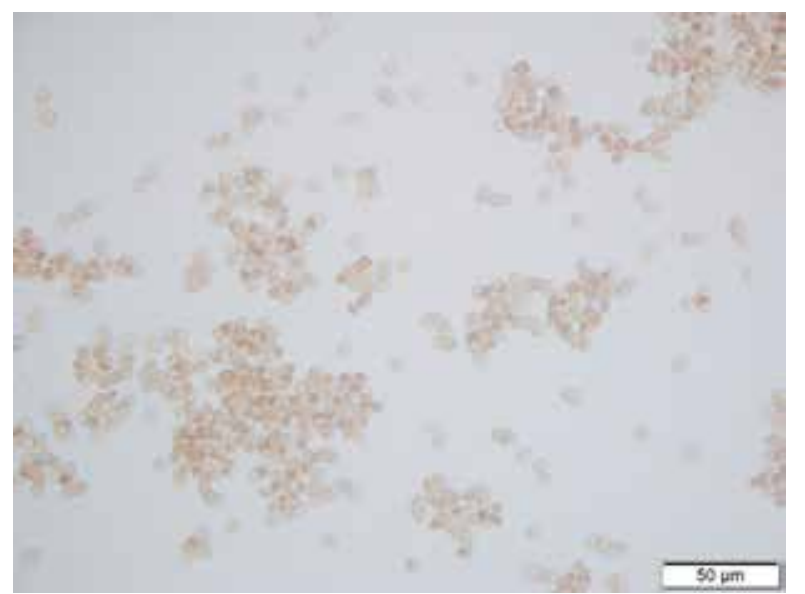

Fig. 3. Polyclonal anti-A serum and A red blood cells in the presence of complement.

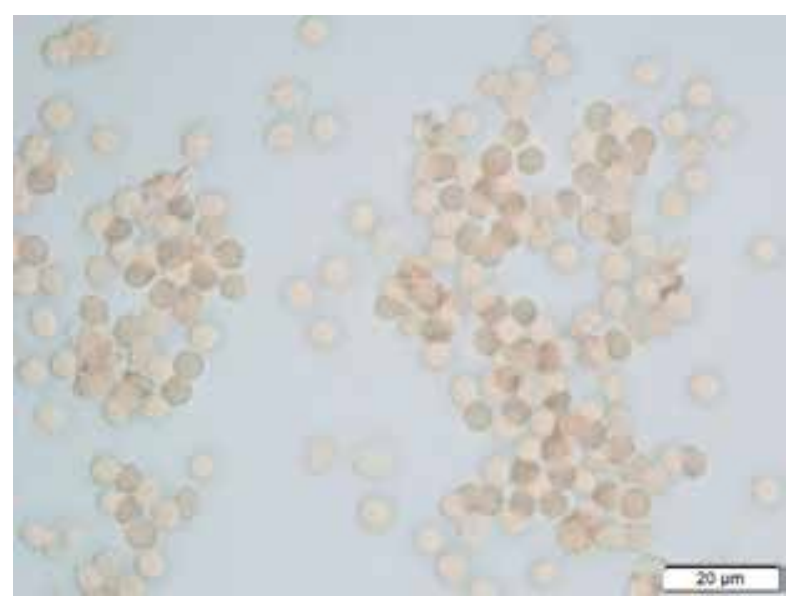

ment in most cases did not lead to agglutination and hemolysis.

\section{Discussion}

AB0 subgroups differ in the number of antigens present on red blood cells. Subgroups A are more common than subgroups B [4]. Subgroups are more often found when there is a discrepancy between the direct and reverse methods of typing groups $[5,6]$. The determination of blood groups is usually carried out in a direct way and rarely the reverse one. As a result, typing may become erroneous. The use of molecular, immunohistochemical, and genetic methods using DNA technologies and genotyping allows one to determine the presence of weak subgroups of the AB0 system [7, 8, 9, 10]. Subgroup B, similar to subgroup A2, is not described, however, cases of determination of erythrocytes in patients that have little or no reaction with anti-B sera have been reported.

Weak $\mathrm{B}$ antigens are proposed to be designated as

Fig. 2. Anti-B serum and $B$ red blood cells in the presence of complement.

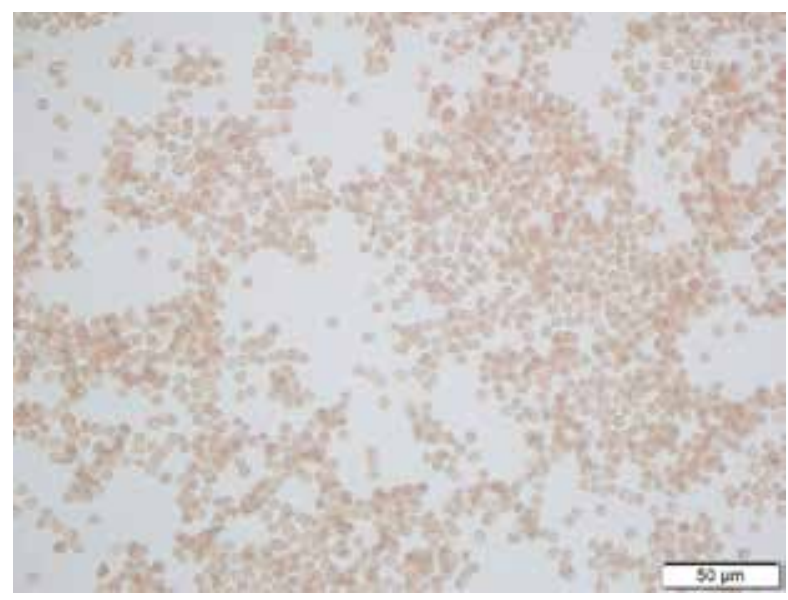

Fig. 4. IgG anti-A serum and A red blood cells in the presence of complement.

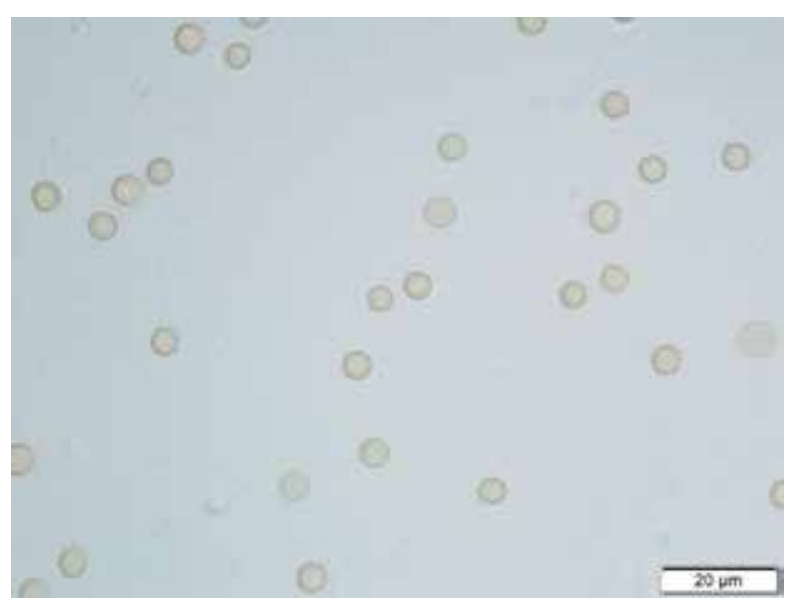




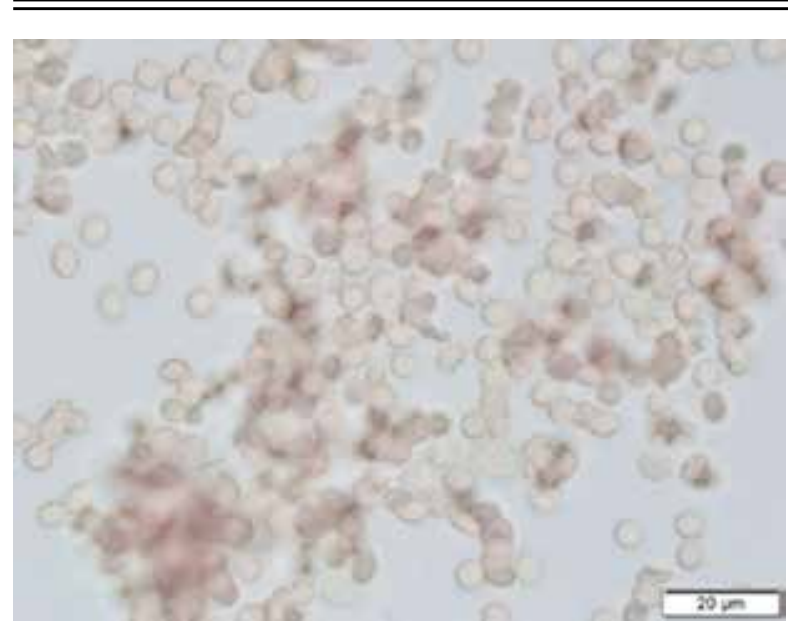

Fig. 5. Polyclonal anti-A, B serum and A red blood cells in the presence of complement.

$\mathrm{B} 3, \mathrm{Bx}, \mathrm{Bm}$ and Bel [5]. Bx is slightly agglutinated and, if present, anti-B antibodies may be present in serum. Thus, the presence of a weak B antigen and anti-B antibody was determined in one of the patients. In this sample (case 5), it was described by some authors [11], and we determined in this work the presence of weak $\mathrm{A}$ and $\mathrm{Bx}$ antigens hemolyzing anti-A and anti-B antibodies. The manifestation of hemolysis of the patient's erythrocytes in the presence of serum and complement could be due to the presence of autoantibodies. Some authors believe that anti-A, anti-B and anti- $\mathrm{AB}$ antibodies reacting at $37^{\circ} \mathrm{C}$ are capable of causing hemolysis in individuals whose erythrocytes lack the corresponding antigens [1]

In agglutination reactions, more pronounced hemolytic activity with the presence of complement was manifested in anti-A serum as compared with anti-B, and may be the result of a higher density of A antigens on erythrocytes and their stronger absorbing ability [1].

It is rather interesting, that the presence of only IgG antibodies and complement led to more pronounced changes in red blood cells compared with the presence of both classes of antibodies.

The presented data are consistent with the existing opinion about a stronger complementbinding and hemolytic ability of $\operatorname{IgG}$ antibodies [5].

The cases presented illustrate the need for additional laboratory methods to detect weak blood group antigens.

This work identifies the benefits of using the antiglobulin test and agglutination reaction in the presence of complement to detect weak A and $\mathrm{B}$ antigens using the whole serum and serum containing only IgG antibodies, which can be achieved after treatment with unithiol.

\section{Conclusions}

1. Typing of blood groups during cross-reaction should be carried out both at room temperature and

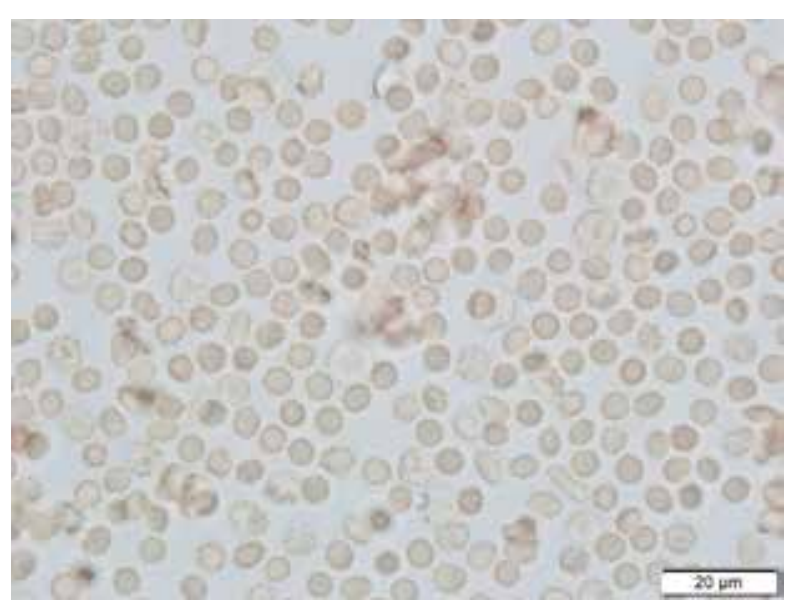

Fig. 6. IgG anti-A, B serum and A red blood cells in the presence of complement.

at $37^{\circ} \mathrm{C}$. An absorption technique and an antiglobulin test with donor serum that has undergone and has not been treated with unithiol, as well as a reaction using complement, can help to identify weak A and $B$ antigens on erythrocytes.

2. The presence of weak antibodies to the corresponding antigens can be detected at room temperature, while $\mathrm{IgG}$ can be detected at $37^{\circ} \mathrm{C}$ using serum after treatment with unithiol in the antiglobulin test. Modulation of the activity of these antibodies can be studied using rheopolyglukin.

3. The use of complement and group-specific antibodies led to a decrease in the size of red blood cells with the corresponding $\mathrm{AB} 0$ phenotype. Increased erythrocyte size and hypochromia have been associated with hemolysis.

\section{Funding}

The work was carried out in accordance with the research plan of Kharkiv National Medical University.

\section{Conflict of interest}

The authors declare that they have no conflict of interest.

\section{Ethical aspects Ethics Committee approval}

The study was approved by Ethics Committee of Kharkiv National Medical University

\section{Informed consent}

Patients agreed to publish the report and posting on the internet the information about the nature of their disease, the survey and its results for scientific and educational purposes. 


\section{ЛИТЕРАТУРА}

1. Heier HE, Namork E, Calkovská Z, Sandin R, Kornstad L. Expression of A antigens on erythrocytes of weakblood group Asubgroups. Vox Sang. 1994;66(3):23136. https://doi.org/10.1111/j.1423-0410.1994.tb00315.x 2. Донсков СИ, Мороков ВР. Группы крови человека: рук по иммуносерологии. Москва, РФ: Бином; 2014. 1016 c. http://www.booksmed. com/allergologiya-immunologiya/3145-gruppy-krovicheloveka-donskov-si.html

3. Subramaniyan R. Diminished expression of B antigen mimicking B3 phenotype in a patient with AML-M3: a rare case report. Rev Bras Hematol Hemoter. 2016 JulSep;38(3):264-66. doi: 10.1016/j.bjhh.2016.05.008 4. Brecher ME, ed. Technical Manual. 14th ed. Bechesda, MD: American Association of Blood Banks; 2002. p. 667.

5. Bryant N. An Introduction to immunohematology. 3rd ed. Philadelphia: W.B. Saunders Co; 1994. p. 115-16, 136. https://doi.org/10.1111/j.1537-2995.1994. tb06021.x

6. Motghare P, Kale L, Bedia AS, Charde S. Efficacy and accuracy of $\mathrm{ABO}$ blood group determination from saliva. JIAOMR. 2011;23(3):163-67. doi: 10.5005/jpjournals-10011-1120

7. Noda H, Yokota M, Tatsumi S, Sugiyama S. Determination of $\mathrm{ABO}$ blood grouping from human oral squamous epithelium by the highly sensitive immunohistochemical staining method EnVision+. J Forensic Sci. 2002 Mar;47(2):341-44. https://doi. org/10.1520/JFS15254J

8. Denomme GA, Rios M, Rcid ME. Molecular Protocols in Transfusion Medicine. London, United Kingdom: Academic Press Publications; 2000. 186 p. https://www.elsevier.com/books/molecular-protocolsin-transfusion-medicine/denomme/978-0-12-209370-8 9. Zhu Z, Ye L, Li Q, Gao H, Tan Y, Cai W. Red Cell Immunohematology research conducted in China. Transfus Med Rev. 2017 Apr;31(2):102-106. doi: 10.1016/j.tmrv.2016.11.004

10. Chun S, Choi S, Yu H, Cho D. Cis-AB, the Blood Group of Many Faces, Is a Conundrum to the Novice Eye. Ann Lab Med. 2019 Mar;39(2):115-20. doi: $10.3343 /$ alm.2019.39.2.115

11. Mohammadi S, Moghaddam M, Babahajian S, Karimian MS, Ferdowsi S. Discrepancy in ABO Blood Grouping in a Blood Donor: a case report. IJBC. 2018; 10(2):61-63. http://ijbc.ir/article-1-795-en.pdf

\section{Адрес для корреспонденции}

61022, Украина,

г. Харьков, пр. Науки, д. 4,

Харьковский национальный медицинский университет,

кафедра внутренней медицины №2,

клинической иммунологии и аллергологии

им. академика Л.Т. Малой,

тел.: +380688888201,

e-mail: valentinka_1987@ukr.net,

Делевская Валентина Юрьевна

\section{Сведения об авторах}

Кравчун Павел Григорьевич, д.м.н., профессор, заведующий кафедрой внутренней медицины № 2, клинической иммунологии и аллергологии

\section{REFERENCE}

1. Heier HE, Namork E, Calkovská Z, Sandin R, Kornstad L. Expression of A antigens on erythrocytes of weakblood group Asubgroups. Vox Sang. 1994;66(3):23136. https://doi.org/10.1111/j.1423-0410.1994.tb00315.x 2. Donskov SI, Morokov VR. Gruppy krovi cheloveka: ruk po immunoserologii. Moscow, RF: Binom; 2014. 1016 p. http://www.booksmed.com/allergologiyaimmunologiya/3145-gruppy-krovi-cheloveka-donskovsi.html (In Russ.)

3. Subramaniyan R. Diminished expression of Bantigen mimicking B3 phenotype in a patient with AML-M3: a rare case report. Rev Bras Hematol Hemoter. 2016 JulSep;38(3):264-66. doi: 10.1016/j.bjhh.2016.05.008

4. Brecher ME, ed. Technical Manual. $14^{\text {th }}$ ed. Bechesda, MD: American Association of Blood Banks; 2002. p. 667.

5. Bryant N. An Introduction to immunohematology. 3rd ed. Philadelphia: W.B. Saunders Co; 1994. p. 115-16, 136. https://doi.org/10.1111/j.1537-2995.1994. tb06021.x

6. Motghare P, Kale L, Bedia AS, Charde S. Efficacy and accuracy of $\mathrm{ABO}$ blood group determination from saliva. JIAOMR. 2011;23(3):163-67. doi: 10.5005/jpjournals-10011-1120

7. Noda H, Yokota M, Tatsumi S, Sugiyama S. Determination of $\mathrm{ABO}$ blood grouping from human oral squamous epithelium by the highly sensitive immunohistochemical staining method EnVision+. J Forensic Sci. 2002 Mar;47(2):341-44. https://doi. org/10.1520/JFS15254J

8. Denomme GA, Rios M, Rcid ME. Molecular Protocols in Transfusion Medicine. London, United Kingdom: Academic Press Publications; 2000. 186 p. https://www.elsevier.com/books/molecular-protocolsin-transfusion-medicine/denomme/978-0-12-209370-8

9. Zhu Z, Ye L, Li Q, Gao H, Tan Y, Cai W. Red Cell Immunohematology research conducted in China. Transfus Med Rev. 2017 Apr;31(2):102-106. doi: 10.1016/j.tmrv.2016.11.004

10. Chun S, Choi S, Yu H, Cho D. Cis-AB, the Blood Group of Many Faces, Is a Conundrum to the Novice Eye. Ann Lab Med. 2019 Mar;39(2):115-20. doi: $10.3343 /$ alm.2019.39.2.115

11. Mohammadi S, Moghaddam M, Babahajian S, Karimian MS, Ferdowsi S. Discrepancy in ABO Blood Grouping in a Blood Donor: a case report. IJBC. 2018; 10(2):61-63. http://ijbc.ir/article-1-795-en.pdf

\section{Address for correspondence}

61022, Ukraine,

Kharkiv, Nauky Ave.,4,

Kharkiv National Medical University,

Department of Internal Medicine №2,

of Clinical Immunology and Allergology

named after Academician L.T.Malaya.

Tel. +380688888201,

e-mail: valentinka_1987@ukr.net,

Dielievska Valentyna Yuriivna

\section{Information about the authors}

Kravchun Pavlo G., MD, Professor, Head of the Department of Internal Medicine №2, of Clinical Immunology and Allergology Named After Academician 
им. академика Л.Т. Малой, Харьковский национальный медицинский университет, г. Харьков, Украина. https://orcid.org/0000-0002-8285-6763

Кожин Михаил Иванович, к.м.н., доцент кафедры внутренней медицины №2, клинической иммунологии и аллергологии им. академика Л.Т. Малой, Харьковский национальный медицинский университет, г. Харьков, Украина.

https://orcid.org/0000-0002-8359-8890

Леонтьева Фрида Соломоновна, к.б.н., заведующая отделом лабораторной диагностики и иммунологии, Институт патологии позвоночника и суставов им. М.И. Ситенко, г. Харьков, Украина. https://orcid.org/0000-0001-9801-7908

Воронцов Петр Михайлович, к.м.н., заведующий отделом экспериментального моделирования и трансплантологии, Институт патологии позвоночника и суставов им. М.И. Ситенко, г. Харьков, Украина. https://orcid.org/0000-0002-5758-7223

Ашукина Наталья Александровна, к.б.н., заведующая лабораторией морфологии соединительной ткани, Институт патологии позвоночника и суставов им. М.И. Ситенко, г. Харьков, Украина. https://orcid.org/0000-0002-0478-7440 Марущак Алексей Поликарпович, врач-ортопедтравматолог высшей категории, Институт патологии позвоночника и суставов им. М.И. Ситенко, г. Харьков, Украина.

https://orcid.org/0000-0002-5606-8763

Делевская Валентина Юрьевна, к.м.н., ассистент кафедры внутренней медицины №2, клинической иммунологии и аллергологии им. академика Л.Т. Малой, Харьковский национальный медицинский университет, г. Харьков, Украина.

\section{Информация о статье}

Поступила 15 января 2019 года.

Принята в печать 15 октября 2019 г. Доступна на сайте 1 ноября 2019 г.
L.T.Malaya, Kharkiv National Medical University, Kharkiv, Ukraine.

https://orcid.org/0000-0002-8285-6763

Kozhyn Mykhailo I., PhD, Associate Professor of the

Department of Internal Medicine №2, of Clinical Immunology and Allergology Named After Academician

L.T.Malaya, Kharkiv National Medical University, Kharkiv, Ukraine.

https://orcid.org/0000-0002-8359-8890

Leontyeva Frida S., PhD, Head of the Department of Laboratory Diagnostics and Immunology, Institute of Spine and Joint Pathology named after M. I. Sytenko, Kharkiv, Ukraine.

https://orcid.org/0000-0001-9801-7908

Vorontsov Petr M., PhD, Head of the Department of Experimental Modeling and Transplantology, Institute of Spine and Joint Pathology named after M. I. Sytenko, Kharkiv, Ukraine.

https://orcid.org/0000-0002-5758-7223

Ashukina Nataliya A., PhD, Head of the Morphology of Connective Tissue, Institute of Spine and Joint Pathology named after M. I. Sytenko, Kharkiv, Ukraine. https://orcid.org/0000-0002-0478-7440

Marushchak Oleksii P., Orthopedist and Traumatologist, Institute of Spine and Joint Pathology named after M. I. Sytenko, Kharkiv, Ukraine.

https://orcid.org/0000-0002-5606-8763

Dielievska Valentyna Y., PhD, Assistant of the Department of Internal Medicine №2, of Clinical Immunology and Allergology Named After Academician L.T.Malaya, Kharkiv National Medical University, Kharkiv, Ukraine.

\section{Article history}

Arrived: 15 January 2019

Accepted for publication: 15 October 2019

Available online: 1 November 2019 